\title{
AKRUAL
}

Jurnal Akuntansi

http://journal.unesa.ac.id/php.index/aj

\section{PENGARUH STRUKTUR ORGANISASI DAN UKURAN PERUSAHAAN TERHADAP PENERAPAN BUSINESS ENTITY CONCEPT}

\author{
Widya Exsa Marita \\ Universitas Negeri Surabaya \\ widyaexsa18@gmail.com
}

\begin{abstract}
Abstrak
Masalah pengelolaan dana merupakan momok yang sering mengakibatkan kegagalan usaha pada suatu perusahaan terutama UMKM. Pengelolaan dana yang efektif dan efisien dapat tercapai jika suatu perusahaan mampu menerapkan akuntansi yang baik. Penerapan akuntansi yang baik haruslah diawali dengan penerapan konsep akuntansi, salah satunya yaitu business entity concept. Penelitian ini bertujuan untuk mengetahui adanya pengaruh struktur organisasi dan ukuran perusahaan terhadap penerapan business entity concept. Objek penelitian yang diambil adalah UD. Agung Mulia Jaya dengan sampel sebanyak 200 reponden yang diambil dengan menggunakan teknik simple random sampling. Variabel bebas dalam penelitian ini adalah struktur organisasi dan ukuran perusahaan, sedangkan variabel terikatnya adalah penerapan business entity concept. Untuk menguji adanya pengaruh struktur organisasi dan ukuran perusahaan terhadap penerapan business entity concept, maka dilakukan analisis regresi linier berganda. Hasil pengujian secara simultan menunjukkan bahwa kedua variabel bebas yaitu struktur organisasi dan ukuran perusahaan berpengaruh terhadap penerapan business entity concept. Secara parsial, struktur organisasi berpengaruh positif terhadap penerapan business entity concept, namun sebaliknya ukuran perusahaan berpengaruh negatif terhadap penerapan business entity concept. Koefisien determinasi menghasilkan nilai $67,4 \%$ yang berarti penerapan business entity concept dapat dijelaskan oleh variabel struktur organisasi dan ukuran perusahaan sebesar $67,4 \%$ atau bersifat kuat.
\end{abstract}

Kata Kunci: business entity concept, pengelolaan dana, struktur organisasi, ukuran perusahaan.

\section{PENDAHULUAN}

Dunia usaha Indonesia memiliki banyak sekali variasi industri baik yang berukuran kecil, sedang ataupun besar. Salah satu bentuk usaha yang ada adalah home industri yang dapat dikatakan sebagai salah satu bentuk usaha mikro, kecil dan menengah (UMKM) karena karakteristiknya yang memenuhi pengertian usaha kecil menurut UU No. 9 tahun 1995 yaitu usaha dengan bentuk usaha dengan kekayaan bersih maksimal Rp 200 juta (tidak termasuk tanah dan bangunan) dengan penjualan tahunan maksimal Rp 1 Milyar. UMKM sendiri telah menjadi tulang punggung perekonomian Indonesia. Hal ini dibuktikan 
dengan tingkat kontribusinya terhadap PDB Indonesia yang mencapai $45 \%$ atau senilai Rp 2.000 triliun ditahun 2009 (Purnamasari, 2013).

Melihat kontribusinya yang cukup signifikan terhadap perekonomian Indonesia, baik pemerintah maupun akademisi banyak yang membahas terkait perkembangan UMKM. Dalam perkembangannya, UMKM khususnya home industri yang ada di Indonesia sedang berproses menjadi usaha yang lebih maju. Terlihat dari data yang dirilis oleh Badan Pusat Statistik pada 14 September 2015 yang menunjukkan bahwa jumlah usaha berskala sedang dan besar ditahun 2014 meningkat sebesar 0,19\% dibanding tahun sebelumnya diikuti dengan penurunan jumlah usaha berskala kecil sebesar 0,22\% . Kenaikan usaha berskala sedang dan besar yang diikuti dengan penurunan usaha kecil dengan tingkat presentase yang cukup dekat ini menunjukkan bahwa penurunan usaha kecil tersebut diakibatkan karena beralihnya usaha kecil tersebut menjadi masuk kedalam usaha berskala sedang dan besar.

Peralihan dari usaha kecil khususnya home industri ke usaha berskala menengah tentunya juga berpengaruh terhadap bagaimana tata kelola atau manajemen pada industri tersebut. Berbicara mengenai tata kelola dan perkembangan suatu industri tentu tidak lepas dari adanya pemisahan tugas dan juga kontrol dari perusahaan yang biasa disebut sebagai struktur organisasi, dimana menurut Gammahendra et al. (2014) untuk menjalankan strategi dari suatu perusahaan memerlukan pengelolaan sumber daya manusia yang baik dan ini dapat diaplikasikan melalui pembentukan suatu strukur organisasi tersebut. Oleh karena itu, untuk mencapai tujuan perusahaan secara efektif dan efisien maka struktur organisasi harus didesain dengan sangat baik (Gammahendra et al., 2014).

Selain masalah tata kelola usaha, tantangan utama yang harus dihadapi adalah terkait dengan pengelolaan dana dari usaha tersebut. Meskipun banyak faktor lain yang mempengaruhi keberhasilan suatu usaha tetapi persoalan-persoalan yang lazimnya muncul adalah akibat kegagalan mengelola dana (Oesman, 2010). Dari sini dapat ditarik sebuah kesimpulan bahwa pengelolaan dana yang baik merupakan salah satu faktor kunci yang dapat menyebabkan keberhasilan atau kegagalan dari suatu usaha baik skala kecil, menengah maupun besar. Metode praktis dan manjur dalam pengelolaan dana pada suatu usaha adalah menerapkan akuntansi yang baik (Purnamasari, 2013).

Penerapan akuntansi yang baik berarti mengharuskan industri menerapkan prinsipprinsip dan konsep akuntansi. Bentuk usaha UMKM seringkali tidak menerapkan adanya pemisahan keuangan bagi diri pribadi dengan kegiatan usahanya terutama usaha yang 
berbentuk perseorangan (Purnamasari, 2013). Ini menunjukkan bahwa salah satu konsep atau teori yang relevan terhadap peralihan skala usaha dari kecil ke sedang atau besar adalah business entity concept atau konsep entitas. Maka, penerapan konsep ini adalah tahapan pertama yang harus dilakukan dalam upaya penerapan akuntansi yang baik oleh usaha yang sedang berkembang menjadi usaha skala sedang dan besar tersebut.

Terdapat banyak faktor yang dapat mempengaruhi penerapan business entity concept sebagai upaya pengelolaan dana salah satunya yaitu ukuran perusahaan (Prasetyorini, 2013). Dalam penelitian Prasetyorini (2013) mengenai ukuran perusahaan dan nilai perusahaan, dinyatakan bahwa perusahaan yang dengan ukuran sedang dan besar dapat tergambar dari total aktiva atau harta yang dimiliki dan juga sumber pendanaan yang dimiliki. Total aktiva yang besar tentunya memerlukan pengelolaan yang lebih dibandingkan total aktiva yang sedikit, sehingga peralihan dari usaha kecil menuju usaha sedang dan besar juga akan berdampak pada jumlah aktivanya sekaligus berdampak pada pengelolaan dananya. Hal ini juga sejalan dengan pernyataan dari Prasetya \& Gayatri (2016) yang menyatakan bahwa ukuran merupakan salah satu variabel yang dapat mempengaruhi bagaimana manajemen suatu perusahaan tidak terkecuali manajemen keuangannya. Dari uraian tersebutlah maka dipilih satu variabel yang diduga dapat mempengaruhi penerapan business entity concept sebagai upaya pengelolaan dana yang baik yaitu ukuran perusahaan.

Gammahendra et al. (2014) melakukan penelitian berbeda mengenai struktur organisasi dan keefektivan strategi organisasi. Penelitian ini menyatakan bahwa dengan adanya struktur organisasi maka dapat diketahui kegiatan apa saja yang ada dalam organisasi, karena didalam struktur organisasi terdapat informasi mengenai bagian-bagian (departemen) yang ada, nama dan posisi masing-masing individu, dimana didalamnya terdapat garis penghubung yang menunjukkan siapa melapor pada siapa dan siapa bertanggungjawab pada siapa. Selain itu, hasil penelitian Gammahendra et al. (2014) juga memberikan pernyataan bahwa selain memberikan kontribusi terhadap keefektivan strategi suatu organisasi, struktur organisasi juga diduga memberikan kontribusi terhadap keefektivan pengelolaan dana yang ada dalam suatu perusahaan. Pernyataan ini sejalan dengan yang dikemukakan oleh Mt, Amri, \& Majid (2014) dalam penelitiannya yang menyatakan bahwa struktur organisasi merupakan salah satu faktor yang mempengaruhi kinerja karyawan dan juga bagaimana tata kelola suatu organisasi termasuk keuangannya.

Dari kelima penelitian yang berbeda diatas, ternyata terdapat unsur kesinambungan dalam hasil penelitiannya. Penelitian Purnamasari (2013) memberikan fakta bahwa 
pengelolaan dana UMKM yang masih menjadi faktor kegagalan usaha dan pernyataan bahwa business entity concept adalah solusinya, penelitian Prasetyorini (2013) yang memberikan salah satu faktor yang dapat mempengaruhi pengelolaan dana yaitu ukuran perusahaan dan penelitian Gammahendra et al. (2014) yang memberikan pernyataan diakhir kesimpulannya bahwa struktur organisasi diduga memiliki kontribusi terhadap keefektivan pengelolaan dana perusahaan. Dari kesinambungan dan dugaan peneliti sebelumnya inilah, maka perlu dilakukan penelitian mengenai apakah terdapat hubungan positif antara pembentukan struktur organisasi, ukuran perusahaan dengan penerapan business entity concept, sehingga nantinya penelitian ini akan menjadi solusi sekaligus menjawab dugaan dari penelitian sebelumnya yang belum diteliti lebih lanjut.

Dalam penelitian ini, penulis memilih untuk menggunakan salah satu usaha yang ada di Desa Punggul RT. 02/RW.02, kecamatan Gedangan, Sidoarjo yaitu UD. Agung Mulia Jaya yang merupakan salah satu contoh home industri yang kini tengah berproses menuju industri yang lebih besar. Industri ini bergerak dibidang industri topi, dasi, kaos kaki, bet sekolah dengan bahan baku berupa kain. Pengambilan industri ini sebagai obyek penelitian dikarenakan pada tahun 2015, UD. Agung Mulia Jaya baru saja memutuskan untuk memperbesar atau mengembangkan usahanya dari home industri menuju usaha berskala menengah dan besar. Salah satu faktor yang dapat digunakan sebagai bukti adalah dengan melihat pergerakan utang bank atau utang jangka panjang lainnya dari usaha tersebut (Oesman, 2010). Satu-satunya utang jangka panjang yang dimiliki UD. Agung Mulia Jaya sendiri adalah utang Bank BRI. Dari data pembukuan perusahaan diperoleh data bahwa diakhir tahun 2014, indutri ini memutuskan untuk meningkatkan utangnya pada Bank BRI sebesar 51\% dibanding tahun sebelumnya atau sebesar Rp 45 juta (2013) menjadi Rp 70 juta (2014). Pada saat itu pula industri ini menambah jumlah karyawannya dari 150 menjadi 235 orang serta mulai membuat struktur organisasi dan mendirikan pabrik khusus karyawan untuk pembuatan produk.

Dari uraian alasan pemilihan obyek pada UD. Agung Mulia Jaya tersebut, maka nantinya penelitian ini akan menghasilkan kesimpulan yang mencerminkan apakah terdapat pengaruh dari pembentukan struktur organisasi dan ukuran perusahaan terhadap penerapan business entity concept khususnya pada usaha kecil yang tengah berproses menuju usaha berskala menengah dan besar. Selain itu, penelitian ini juga bisa menjadi acuan bagi home industri maupun usaha kecil lainnya untuk berupaya menerapkan salah satu prinsip akuntansi yaitu business entity concept dengan baik, sehingga masalah utama dari usaha kecil terkait pengelolaan dana dapat teratasi. 


\section{METODE.}

\section{Desain Penelitian}

Penelitian ini bertujuan untuk mendapatkan gambaran tentang adanya korelasi dan tingkat signifikansi pengaruh antara pembentukan struktur organisasi dan ukuran perusahaan dengan penerapan business entity concept pada UD. Agung Mulia Jaya. Perhitungan atau pendekatan yang digunakan adalah pendekatan kuantitatif yang artinya menggunakan perhitungan ilmiah yang berasal dari sampel individu dalam suatu obyek penelitian dengan memintanya menjawab sebuah survei (Lind et al., 2014). Hasil survei inilah yang nantinya akan menunjukkan frekuensi dan presentase tanggapan mereka mengenai pokok bahasan yang sedang diteliti. Dalam penelitian ini akan diuji adanya pengaruh (hubungan) antara variabel bebas (X) terhadap variabel terikat (Y), sehingga dikatakan bahwa sifat dari penelitian ini adalah asosiatif kausal (Sugiyono, 2009). Variabel yang dirumuskan dalam penelitian ini terdiri dari variabel bebas (independent variable) yaitu struktur organisasi (X1) dan ukuran perusahaan (X2) serta variabel terikatnya (dependent variable) yaitu penerapan business entity concept (Y) pada UD. Agung Mulia Jaya.

\section{Populasi \& Sampel}

Menurut Sugiyono (2009), populasi merupakan keseluruhan objek yang akan diteliti yang memiliki kualitas dan karakteristik tertentu, dimana karakteristik tersebut telah ditetapkan oleh peneliti dan kemudian akan ditarik kesimpulan. Populasi dari penelitian ini sendiri yaitu seluruh karyawan yang ada di UD. Agung Mulia Jaya. Pada perusahaan ini, jumlah karyawan pada tahun penelitian yaitu tahun 2016 adalah sebanyak 235 orang.

Sampel merupakan porsi atau bagian yang diambil peneliti dari populasi penelitian (Lind et al., 2014). UD. Agung Mulia Jaya memiliki karyawan sebanyak 235 orang yang kemudian diambil sampel sebanyak 200 orang. Menurut tabel Issac Michael, ukuran pengambilan sampel untuk tingkat signifikansi 0,05 dengan jumlah populasi 240 orang adalah sebanyak 142, namun peneliti menambahkan sampel sampai ke tingkat 200 untuk menghindari adanya ketidaklengkapan data serta untuk tujuan pengolahan data. Teknik sampling yang digunakan yaitu probability sampling dengan pendekatan simple random sampling, yaitu pengambilan sampel yang dilakukan secara acak sehingga setiap individu dalam populasi memiliki kesempatan yang sama (Lind et al., 2014). 


\section{Sumber Data}

Dalam upaya pengumpulan data, penelitian ini menggunakan data berupa data primer. Data primer merupakan data yang didapatkan oleh peneliti secara langsung dari sumber informasi (Lind et al., 2014). Sumber informasi yang dimaksud adalah berdasarkan pada tanggapan dari karyawan UD. Agung Mulia Jaya yang dijadikan sampel dari penelitian ini. Dalam mengambil sampel, peneliti meminta bantuan dari pihak pemilik perusahaan dan juga manajer dari tiap-tiap bagian yang ada dalam perusahaan. Hal ini dilakukan agar sampel yang diambil akurat dan dapat mewakili seluruh populasi yang ada di perusahaan tersebut.

\section{Teknik Pengumpulan Data}

Dalam penelitian ini, peneliti menggunakan teknik pengumpulan dengan metode penelitian lapangan (Field Research). Pendekatan yang dilakukan dalam upaya pengumpulan data meliputi:

a. Kuisioner jenis closed questionare. Pendekatan ini merupakan cara pengumpulan data dengan meminta tanggapan responden atas pernyataan yang ada dalam kuisioner (Sugiyono, 2009). Pada jenis closed questionare kuisioner yang dibagikan sudah memuat pilihan jawaban, sehingga responden hanya perlu memilih jawaban atas tanggapan mereka.

b. Wawancara (Interview). Pendekatan ini dilakukan dengan melakukan tanya jawab langsung dengan narasumber (Sugiyono, 2009). Dalam hal ini, peneliti memilih melakukan wawancara dengan pemilik perusahaan serta bagian akuntansi dalam perusahaan.

\section{Instrumen Penelitian}

Metode kuisioner merupakan instrumen utama yang digunakan dalam upaya mengumpulkan data yang diperlukan pada penelitian ini. Kuisioner yang dibagikan sendiri merupakan jenis closed questionaire yang merupakan hasil modifikasi peneliti dari sumber penelitian terdahulu yaitu penelitian milik Gammahendra et al., (2014), Putu et al., (2016) dan Oesman (2010). Modifikasi ini dilakukan untuk melakukan penyesuaian terhadap objek penelitian maupun responden yang diajukan.

Hasil dari kuisioner yang telah dibagikan nantinya akan diolah menjadi data angka dengan menggunakan model Linkert Scale (Skala Linkert). Skala linkert merupakan skala yang digunakan untuk mengukur pendapat, sikap dan persepsi seseorang terhadap suatu 
keadaan tertentu (Sugiyono, 2009). Pada penelitian ini, digunakan skala linkert dengan rentang skala 1 sampai dengan 5. Pemilihan rentang 1 sampai 5 ini dikarenakan menurut Gammahendra et al., (2014) dalam penelitiannya, untuk mengukur suatu penerapan sistem melalui kuisioner atau pernyataan maka responden harus benar-benar yakin dengan tanggapan yang diberikan, maka skala yang diberikan juga harus lebih komprehensif.

Dalam upaya untuk mengoptimalkan informasi terkait UD. Agung Mulia Jaya, peneliti juga melakukan pengumpulan data dengan metode wawancara dengan pemilik perusahaan dan juga karyawan bagian keuangan. Wawancara ini dimaksudkan untuk mengetahui bagaimana seluk beluk perusahaan serta bagaimana sistem pengambilan keputusan maupun pemrosesan keuangan perusahaan. Peneliti menetapkan wawancara tersebut dilakukan dengan pihak pemilik perusahaan karena UD. Agung Mulia Jaya sendiri awalnya adalah home industri yang mana dalam perusahaan seperti ini pemilik merupakan penanggungjawab penuh semua kegiatan perusahaan. Peneliti juga merasa perlu melakukan wawancara dengan pihak keuangan dengan alasan bahwa jalan untuk penerapan business entity concept adalah pada bagian pencatatan dan pengakuan atas transaksi yang ada dalam perusahaan (Jones, 2014).

\section{Teknik Analisis Data}

\section{Analisis Deskriptif}

Penelitian ini mengandung dua variabel bebas yaitu struktur organisasi dan ukuran perusahaan serta satu variabel terikat yaitu penerapan business entity concept, sehingga teknik analisis data yang digunakan adalah analisis regresi linier berganda dengan bantuan software SPSS 23 for Windows. Analisis regresi linier berganda merupakan suatu metode yang digunakan untuk mengetahui adanya hubungan linier antara beberapa variabel bebas dengan variabel terikatnya (Lind et al., 2014). Dengan analisis ini, akan diketahui apakah terdapat pengaruh antara struktur organisasi dan ukuran perusahaan terhadap penerapan business entity concept itu sendiri. Selain itu analisis ini juga digunakan untuk mengetahui berapa tingkat signifikansi hubungan antara variabelvariabel yang telah dirumuskan. Persamaan fungsinya dirumuskan sebagai berikut: 
$Y=\alpha+\beta 1 X 1+\beta 2 X 2$

Dimana:

$$
\begin{array}{ll}
\mathrm{Y} & =\text { Penerapan business entity concept } \\
\alpha & =\text { Konstanta } \\
\beta 1, \beta 2 & =\text { Koefisien } \\
\mathrm{X} 1 & =\text { Struktur organisasi } \\
\mathrm{X} 2 & =\text { Ukuran perusahaan }
\end{array}
$$

Sebelum analisis regresi berganda dilakukan, maka perlu dilakukan pengujian asumsi klasik untuk memastikan bahwa model yang digunakan telah terhindar dari masalah linieritas, heteroskedastisitas, multikolinieritas dan juga normalitas (Lind et al., 2014). Selain melakukan pengujian terhadap model yang digunakan, dalam penelitian ini juga diperlukan uji validitas dan uji reliabilitas terkait dengan kuisioner yang digunakan dalam pengambilan data. Uji kuisioner ini dilakukan untuk memastikan bahwa kuisioner yang dibagikan merupakan alat ukur yang benar-benar dapat menginterpretasikan variabel yang akan diukur.

Berikut ini merupakan langkah-langkah pengujian yang dilakukan dalam penelitian ini:

\section{Uji Validitas dan Reliabilitas}

Penelitian ini menggunakan teknik pengumpulan data berupa kuisioner, sehingga perlu dilakukan pengujian atas keabsahan dari kuisioner tersebut melalui uji validitas. Uji validitas sendiri bertujuan untuk mengetahui apakah alat ukur yang digunakan sesuai atau mampu mengukur apa yang sebenarnya ingin diukur. Validitas dari masing-masing pernyataan dalam kuisioner dapat dilakukan dengan mengkorelasikan skor setiap pernyataan dengan jumlah skor totalnya (Sugiyono, 2009). Nilai korelasi yang dimaksud yang selanjutnya disebut sebagai $\mathrm{r}$ hitung dapat dilihat dari nilai Pearson Correlation. Nilai ini kemudian dibandingkan dengan nilai $r$ tabel dengan ketentuan sebagai berikut:

a. Jika $r$ hitung lebih besar dari $r$ tabel, maka pernyataan tersebut dinyatakan lolos uji validitas dan dianggap valid

b. Jika $r$ hitung lebih kecil dari $r$ tabel, maka pernyataan tersebut tidak lolos uji validitas dan harus diperbaiki atau dibuang

Selain uji validitas, penelitian yang menggunakan teknik pengumpulan data berupa kuisioner juga harus melewati uji reliabilitas. Reliabilitas suatu pernyataan menunjukkan tingkat konsistensi dari tanggapan responden terhadap pernyataan tersebut dari waktu ke waktu (Ghozali, 2011). Sama dengan uji validitas, pengujian reliabilitas juga dilakukan 
dengan membandingkan nilai $r$ tabel dan $r$ hitung. Perbedaannya adalah pada uji reliabilitas, nilai $\mathrm{r}$ hitung dilihat pada nilai Cronbrabch's Alpha masing-masing variabel. Ketentuan yang digunakan dalam pengujian reliabilitas adalah:

a. Jika nilai Cronbrabch's Alpha sebagai r hitung lebih besar dari r tabel, maka pernyataan tersebut dinyatakan lolos uji reliabilitas dan dianggap reliabel

b. Jika Cronbrabch's Alpha sebagai $\mathrm{r}$ hitung lebih kecil dari $\mathrm{r}$ tabel, maka pernyataan tersebut tidak lolos uji reliabilitas dan harus diperbaiki atau dibuang

\section{Uji Asumsi Klasik}

\subsection{Uji Linieritas}

Pengujian linieritas merupakan langkah uji asumsi klasik yang digunakan untuk mengetahui bahwa hubungan antara sekelompok variabel bebas dengan variabel terikat bersifat linier. Dalam penelitian ini, uji linieritas dilakukan menggunakan diagram pencar (scatter plot). Gambar grafik atau diagram pencar yang dihasilkan nantinya akan membantu memvisualisasikan hubungan antara variabel terikat dengan masing-masing variabel bebasnya. Selain itu, grafik ini juga akan memberikan informasi awal mengenai arah pengaruhnya (positif atau negatif) dan bagaimana kekuatan hubungannya dengan ketentuan sebagai berikut :

a. Jika titik-titik dalam plot pencar antara $\mathrm{X}$ dan $\mathrm{Y}$ menghasilkan slop positif atau bergerak beriringan, maka dikatakan bahwa hubungan linier bersifat positif

b. Jika titik-titik dalam plot pencar antara $\mathrm{X}$ dan $\mathrm{Y}$ menghasilkan slop negatif atau bergerak berlawanan, maka dikatakan bahwa hubungan linier bersifat negative

\subsection{Uji Heteroskedastisitas}

Heteroskedastisitas adalah pengujian yang bertujuan untuk menguji apakah variance residual yang ada disekitar persamaan regresi tidak sama untuk seluruh nilai variabelnya (Lind et al., 2014). Jika variance residual tetap atau konstan, maka artinya adalah residual bersifat homogen (homoskedastisitas) dan sebaliknya jika variance residual berbeda maka disebut heteroskedastisitas atau bersifat heterogen (Ghozali, 2011). Sesuai dengan asumsi klasik dari analisis regresi linier berganda, maka variance residual yang baik adalah yang bersifat homogen atau tidak terjadi heteroskedastisitas (Ghozali, 2011).

Pengujian heteroskedastisitas dapat dilakukan dengan melihat scatterplot antara nilai dependent variable ZPRED dengan nilai residual SRESID (Lind et al., 2014). Deteksi ada tidaknya heteroskedastisitas dapat dilakukan dengan melihat ada tidaknya 
pola terntu dalam scatterplot antara ZPRED dan SRESID dimana sumbu Y adalah sumbu $\mathrm{Y}$ adalah sumbu yang telah diprediksi dan sumbu $\mathrm{X}$ adalah residual yang telah di studentized. Kriteria yang digunakan dalam penentuan terdapatnya heteroskedastisitas adalah sebagai berikut:

a. Apabila dalam scatterplot terlihat adanya titik-titik yang membentuk suatu pola tertentu (menyatu), maka hal ini mengidentifikasikan telah terjadi heteroskedastisitas

b. Apabila dalam scatterplot tidak terlihat adanya titik-titik yang membentuk suatu pola tertentu (menyebar), maka hal ini mengidentifikasikan bahwa tidak terjadi heteroskedastisitas atau dengan kata lain variasi bersifat homogeny

\subsection{Uji Multikolinieritas}

Multikolinieritas terjadi sebagai akibat adanya korelasi antar variabel bebas yang diajukan (Lind et al., 2014). Variabel bebas yang berkorelasi akan mengakibatkan kesulitan dalam pengambilan keputusan terhadap masing-masing koefisien regresi beserta pengaruhnya terhadap variabel terikat. Menurut Lind et al. (2014) model regresi dikatakan baik jika tidak terdapat korelasi diantara variabel bebasnya (multikolinieritas). Cara mengidentifikasi adanya multikolinieritas adalah dengan melihat nilai dari variance inflation factor (VIF). Aturan umumnya adalah jika nilai VIF > 10, maka nilai ini dianggap kurang memuaskan atau terjadi multikolinieritas dan ini menunjukkan bahwa beberapa variabel bebas harus dihilangkan dari penelitian (Lind et al., 2014).

\subsection{Uji Normalitas}

Uji normalitas merupakan pengujian yang dilakukan untuk memastikan bahwa residual mengikuti pola distribusi normal (Lind et al., 2014). Hal ini perlu dilakukan untuk memperkuat keyakinan bahwa hasil uji hipotesis dalam penelitian ini benar-benar akurat dan sahih. Pengujian normalitas dilakukan dengan menggunakan uji Kolomogorov-Smirnov (Lind et al., 2014). Dalam pengujian ini, hipotesis yang dirumuskan adalah :

Ho : data berdistribusi normal

Ha : data tidak berdistribusi normal

Nilai yang dijadikan acuan dalam pengujian normalitas adalah nilai Assymp.Sig (2-tailed) dalam hasil output SPSS 23 for Windows. Jika nilai dalam tersebut lebih besar dari alpha atau $(\mathrm{Sig})>0,05$, maka disimpulkan bahwa H0 diterima dan dengan kata lain 
data telah berdistribusi normal. Sebaliknya jika nilai dalam perhitungan lebih kecil dari alpha atau (Sig) < 0,05, ini berarti H0 ditolak dan H1 diterima dengan kesimpulan bahwa data tidak berdistribusi normal (Lind et al., 2014).

Selain menggunakan uji kolomogorov smirnov, uji normalitas juga dapat ditunjukkan dengan melihat normal probability plot. Dalam melihat grafik tersebut, maka dasar pengambilan keputusan yang digunakan yang digunakan menurut Ghozali (2011) adalah sebagai berikut:

a. Jika titik-titik dalam grafik menyebar disekitar garis diagonal dan mengikuti arah garis diagonal atau gambar histogramnya menunjukkan distribusi normal, maka dikatakan bahwa model regresi telah memenuhi asumsi normalitas

b. Jika titik-titik dalam grafik menyebar jauh dan tidak mengikuti arah garis diagonal atau gambar histogramnya tidak menunjukkan distribusi normal, maka dikatakan bahwa model regresi telah melanggar asumsi normalitas.

\section{Uji Signifikansi Simultan (Uji F)}

Uji F diperlukan untuk mengetahui adanya pengaruh simultan dari semua variabel bebas yang dirumuskan terhadap variabel terikatnya (Lind et al., 2014). Dalam melakukan pengujian pengaruh simultan ini, hal pertama yang dilakukan adalah dengan merumuskan hipotesis sebagai berikut:

Ho : $\beta 1, \beta 2=0$, artinya tidak ada pengaruh struktur organisasi dan ukuran perusahaan terhadap penerapan business entity concept

Ha $\quad: \beta 1, \beta 2 \neq 0$, artinya terdapat pengaruh struktur organisasi dan ukuran perusahaan terhadap penerapan business entity concept

Tingkat signifikansi kesalahan atau alpha yang digunakan dalam penelitian adalah 0,05 sehingga pengambilan keputusan atas hipotesis yang dipaparkan adalah sebagai berikut:

a. Jika nilai F-hitung > alpha $(0,05)$, maka disimpulkan bahwa H0 diterima atau tidak ada pengaruh struktur organisasi dan ukuran perusahaan terhadap penerapan business entity concept

b. Jika nilai F-hitung < alpha $(0,05)$, maka disimpulkan bahwa H0 ditolak dan H1 diterima atau terdapat pengaruh struktur organisasi dan ukuran perusahaan terhadap penerapan business entity concept. Dan ini menunjukkan bahwa model tersebut memang layak atau cocok untuk untuk memprediksi variabel terikatnya. 


\section{Uji Parsial (Uji t)}

Uji t pada dasarnya dilakukan untuk menguji pengaruh dari masing-masing variabel bebas terhadap variabel terikatnya (Lind et al., 2014). Variabel bebas yang dimaksud adalah struktur organisasi dan ukuran perusahaan, sedangkan variabel terikatnya yaitu penerapan business entity concept. Dalam penelitian ini, peneliti menggunakan tingkat signifikansi kesalahan (alpha) 5\% atau 0,05. Dalam melakukan pengujian parsial atau uji $\mathrm{t}$, hipotesis yang dirumuskan untuk masing-masing variabel bebas adalah sebagai berikut:

a. Pengaruh struktur organisasi terhadap penerapan business entity concept

H01 $: \beta<0$, artinya struktur organisasi tidak berpengaruh positif terhadap penerapan business entity concept

Ha1 : $\beta>0$, artinya struktur organisasi berpengaruh positif terhadap penerapan business entity concept.

b. Pengaruh ukuran perusahaan terhadap penerapan business entity concept

Ho2 $: \beta<0$, artinya ukuran perusahaan tidak berpengaruh positif terhadap penerapan business entity concept

Ha2 : $\beta>0$, artinya ukuran perusahaan berpengaruh positif terhadap penerapan business entity concept.

Setelah hipotesis dirumuskan, maka langkah selanjutnya dalam uji parsial adalah membuat dasar pengambilan keputusan untuk semua hipotesis tersebut. Pengambilan keputusan didasarkan pada nilai probabilitas hasil pengolahan data dengan SPSS 23 for Windows dengan ketentuan:

- Jika Probabilitas > alpha $(0,05)$, maka H0 diterima

- Jika probabilitas < alpha $(0,05)$, maka H0 ditolak dan H1 diterima

\section{Koefisien Determinasi (R Square)}

Koefisien determinasi adalah proporsi dari variasi total pada variabel terikat yang mampu dijelaskan oleh variabel bebas (Lind et al., 2014). Koefisien determinasi sangat mudah dihitung karena merupakan koefisien korelasi yang dikuadratkan atau bisa disebut $R$ square. $\mathrm{R}^{2}$ ini juga dapat digunakan untuk melihat apakah persamaan regresi dari penelitian yang dilakukan mampu memprediksi variabel terikatnya (Y). Nilai dari koefisien determinasi adalah berkisar antara 0 sampai dengan 1, dimana nilai yang mendekati 0 memiliki arti bahwa kemampuan variabel bebas yang diajukan dalam menjelaskan variabel terikat sangatlah terbatas, sebaliknya jika nilai $\mathrm{R}^{2}$ mendekati 1 
berarti varibel bebas yang diajukan hampir memberikan seluruh informasi yang dibutuhkan untuk memprediksi variabel terikatnya (Ghozali, 2011).

\section{HASIL DAN PEMBAHASAN}

\section{Uji Validitas dan Reliabilitas}

Pengujian ini dilakukan terhadap masing-masing variabel penelitian dimana keseluruhan variabel memiliki 28 pernyataan yang ada dalam kuisioner. Kriteria yang digunakan dalam menilai valid tidaknya pernyataan tersebut adalah menggunakan tingkat kepercayaan $95 \%(\alpha=0,05)$, degree of fredom $(\mathrm{df})=\mathrm{n}-2=200-2=198$, dan diperoleh nilai $\mathrm{r}$ tabel 0,1197. Jika nilai dari $\mathrm{r}$ hitung yang ditunjukkan pada kolom Pearson Correlation bernilai positif dan juga lebih besar dibandingkan $r$ tabel, maka pernyataan tersebut dinyatakan valid (Ghazali, 2011). Berdasarkan uji yang dilakukan, semua pertanyaan yang diajukan dalam penelitian telah dinyatakan valid dan memiliki nilai $r$ hitung $>\mathrm{r}$ tabel.

Pengujian reliabilitas merupakan pengujian yang dilakukan pada masing-masing variabel penelitian. Hasil uji ini akan menunjukkan kehandalan dari kuisioner penelitian. Kuisioner dianggap reliabel jika jawaban responden terhadap pernyataan yang ada dalam kuisioner adalah stabil dari waktu ke waktu (Ghazali, 2011). Reliabel atau tidaknya masing-masing variabel dapat dilihat dengan membandingkan $r$ hitung dan $r$ tabel, dimana dalam uji reliabilitas nilai $r$ hitung adalah ditunjukkan pada Cronbrach's Alpha . Ketentuan yang digunakan adalah jika $\mathrm{r}$ hitung lebih besar dari $\mathrm{r}$ tabel, maka pernyataan dalam variabel yang diuji sudah reliabel. Dari hasil pengujian, semua variabel telah memiliki nilai $r$ hitung $>r$ tabel sehingga kuisioner disimpulkan telah valid dan reliable.

\section{Uji Asumsi Klasik}

\section{Uji Linieritas}

Pengujian linieritas dilakukan dengan melakukan pengujian terhadap diagram pencar (scatter plot) pada masing-masing independent variable $(\mathrm{X})$ terhadap dependent variable (Y), sehingga gambar tersebut akan memberikan informasi awal apakah variabel bebas memiliki hubungan linier postif atau negatif terhadap variabel terikatnya. Berikut ini hasil pengujian yang telah dilakukan. 

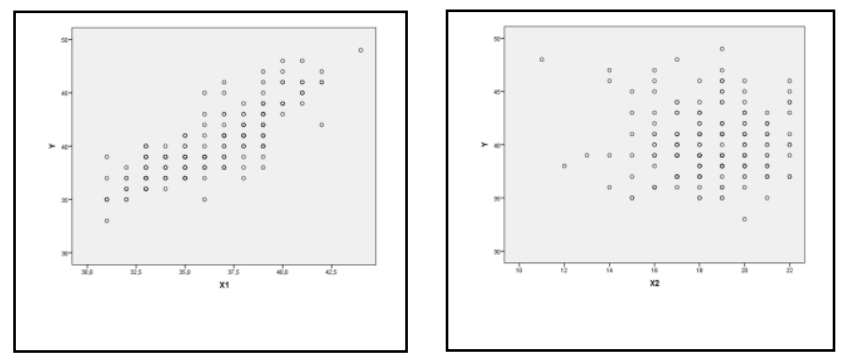

Gambar 1. Scatter plot $\mathrm{X}_{1}$ dan $\mathrm{X}_{2}$ terhadap $\mathrm{Y}$

Dari gambar scatter plot pada masing-masing variabel bebas terhadap variabel terikat diatas, dapat dilihat bahwa kedua variabel bebas memiliki hubungan linier yang berbeda. Struktur organisasi (X1) memiliki hubungan linier positif terhadap penerapan business entity concept (Y), ini ditunjukkan oleh titik-titik yang ada dalam diagram pencar memiliki slop positif atau bergerak beriringan. Sebaliknya, ukuran perusahaan (X2) dikatakan memilihi hubungan linier negatif terhadap penerapan business entity concept (Y), ini digambarkan pada titik-titik dalm diagram pencar yang terlihat tak beraturan dan bergerak berlawanan atau tidak membentuk slop positif. Gambaran awal mengenai hubungan linier ini nantinya akan diuji kembali dan diketahui hasil angkanya dalam persamaan linier yang dirumuskan pada analisis regresi linier berganda selanjutnya

\section{Uji Heterokedastisitas}

Pengujian heterokedastisitas dilakukan untuk mengetahui adanya ketidaksamaan pada variance residual untuk seluruh variabelnya (Lind et al., 2014). Ada tidaknya heteroskedastisitas ini dapat dilihat pada scatterplot nilai ZPRED (dependent variable) dan SRESID (nilai residual) berikut ini.

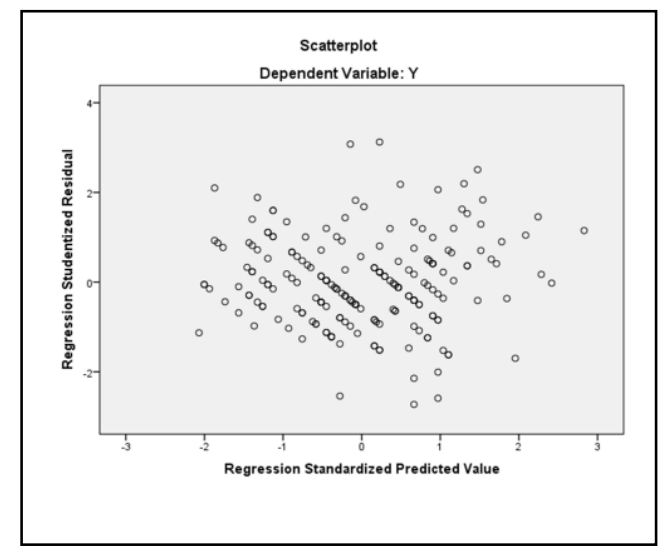

Gambar 2. Scatter plot ZPRED dan SRESID

Hasil pengujian heteroskedastisitas diatas menunjukkan bahwa dalam scatterplot tidak terlihat adanya titik-titik yang menyatu atau menbentuk pola tertentu. 
Hal ini menunjukkan bahwa tidak terjadi heteroskedastisitas pada semua variabel penelitian atau variasi dari semua variabel bersifat homogen.

\section{Uji Multikolinieritas}

Pengujian ada tidaknya hubungan atau korelasi antar variabel bebas penelitian disebut uji multikolinieritas (Lind et al., 2014). Pengujian ini dilakukan dengan membandingkan nilai variance inflation factor (VIF) pada masing-masing variabel bebasnya, dengan ketentuan jika nilai VIF lebih besar dari 10 maka dikatakan bahwa antar variabel bebas telah terjadi multikolinieritas. Hasil uji multikolinieritas ditunjukkan pada tabel berikut ini.

Tabel 1. Hasil Uji Multikolinieritas

\begin{tabular}{lll}
\hline Variabel & Nilai VIF & Keterangan \\
\hline Struktur Organisasi $\left(\mathrm{X}_{1}\right)$ & 1,010 & Tidak terjadi multikolinieritas \\
Ukuran Perusahaan $\left(\mathrm{X}_{2}\right)$ & 1,010 & Tidak terjadi multikolinieritas
\end{tabular}

Hasil pengujian dalam tabel 1 tersebut menunjukkan bahwa nilai VIF dari masing-masing variabel bebas tidak lebih besar dari 10, sehingga dikatakan bahwa tidak terjadi multikolinieritas atau tidak ada korelasi antara variabel bebas yang dirumuskan.

\section{Uji Normalitas}

Uji normalitas digunakan untuk mengetahui apakah distribusi residu telah terdistribusi normal atau tidak. Pengujian ini dapat dilakukan dengan menggunakan teknik Kolmogorov Smirnov (Lind et al., 2014). Hasil pengujian dapat dilihat pada bagian Assymp.Sig. (2-tailed), kemudian dibandingkan dengan tingkat signifikansi (alpha) yang telah ditentukan sebelumnya yaitu sebesar 0,05. Hasil pengujian normalitas dapat dilihat pada hasil output SPSS 23 for Windows berikut ini.

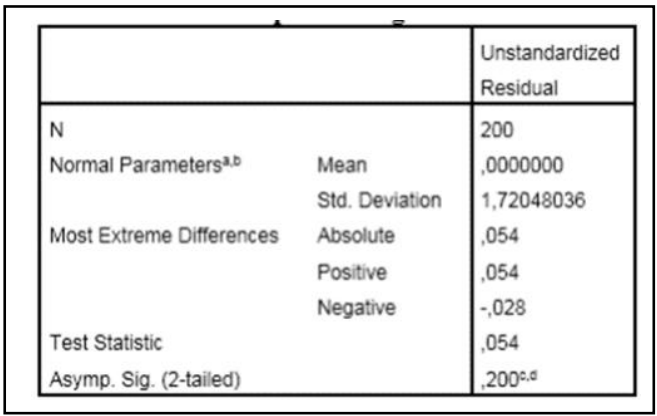


Hasil output diatas menunjukkan bahwa nilai Assymp.Sig. (2-tailed) sebesar 0,200 dan lebih besar dari 0,05, sehingga ini menghasilkan kesimpulan bahwa Ho yang dirumuskan sebelumnya diterima atau dengan kata lain data telah berdistribusi normal. Untuk meyakinkan peneliti bahwa data telah berdistribusi normal, maka peneliti juga melakukan pengujian dengan melihat normal probability plot berikut ini.
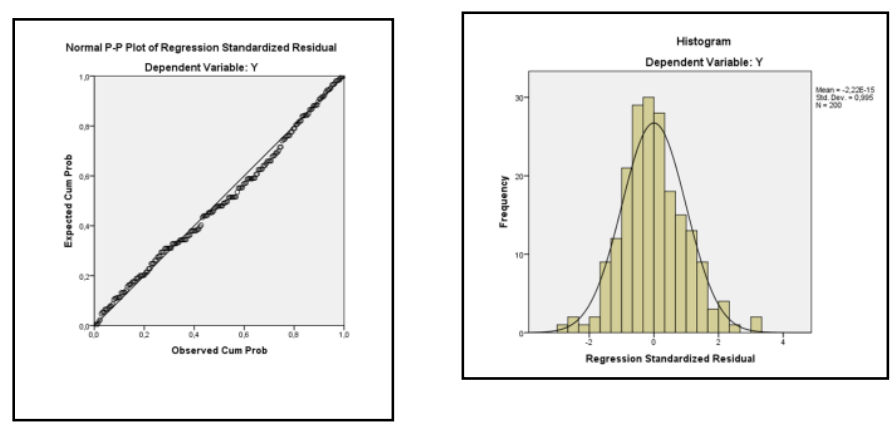

\section{Gambar 4. Normal P-Plot dan Histogram}

Dari gambar 4 yang ditunjukkan diatas, terlihat bahwa titik-titik yang ada dalam grafik menyebar disekitar garis diagonal dan mengikuti arah garis daigonal serta histogram data pada gambar 6 tersebut juga menunjukkan bahwa data sudah berdistribusi normal. Hasil pengujian ini memperkuat hasil uji Kolmogorov Smirnov yang dilakukan sebelumnya yaitu dengan kesimpulan bahwa data telah berdistribusi normal atau tidak melanggar asumsi normalitas.

\section{Hasil Pengujian Hipotesis}

Dalam upaya untuk mengetahui apakah hipotesis yang dirumuskan terpenuhi atau tidak, maka dilakukan pengujian menggunakan analisis regresi linier berganda. Penggunaan analisis regresi linier berganda ini dilakukan karena peneliti merumuskan lebih dari satu variabel bebas, sehingga analisis yang cocok adalah analisis model berganda (Lind et al., 2014). Hasil pengujian ini nantinya akan menunjukkan apakah variabel bebas yang dirumuskan berpengaruh terhadap variabel terikatnya. Jika variabel bebas berpengaruh, maka akan diketahui pula seberapa besar pengaruhnya terhadap variabel terikat. Berikut ini disajikan hasil dari analisis regresi linier berganda yang telah dilakukan.

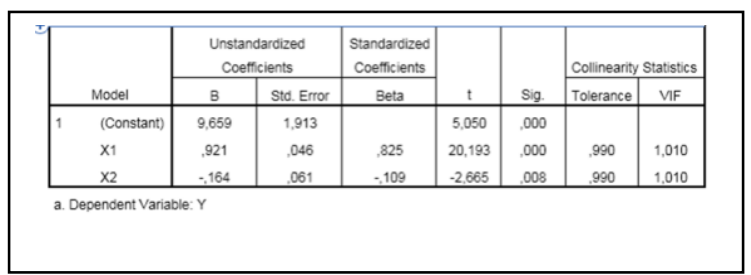

Gambar 5. Coefficients 
Analisis regresi linier berganda tersebut kemudian dirumuskan dalam bentuk persamaan regresi linier berganda sebagai berikut:

$\mathrm{Y}=9,659+0,921 \mathrm{X} 1-0,164 \mathrm{X} 2$

Dimana:

$\mathrm{Y} \quad=$ Penerapan business entity concept

$\alpha \quad=$ Konstanta

$\beta 1, \beta 2=$ Koefisien

$\mathrm{X} 1=$ Struktur organisasi

$\mathrm{X} 2=$ Ukuran perusahaan

Dalam persamaan tersebut, nilai konstanta $(\alpha)$ adalah sebesar 9,659 yang berati jika tidak ada perubahan pada variabel bebas yaitu struktur organisasi dan ukuran perusahaan, maka nilai dari penerapan business entity concept sebagai variabel terikatnya adalah sebesar 9,659. Persamaan diatas juga menunjukkan bahwa struktur organisasi berpengaruh positif terhadap penerapan business entity concept sedangkan ukuran perusahaan berpengaruh negatif terhadap penerapan business entity concept, yang mana hal ini dapat dilihat pada nilai koefisien $(\beta)$ dari masing-masing variabel bebas yaitu sebesar 0,921 dan $-0,164$. Nilai koefisien X1 sebesar 0,921 tersebut mengandung arti bahwa jika variabel struktur organisasi mengalami kenaikan dan variabel lainnya dianggap konstan, maka variabel penerapan business entity concept juga akan mengalami kenaikan sebesar 0,921. Selanjutnya yaitu nilai koefisien X2 sebesar -0,164 mengandung arti bahwa jika variabel ukuran perusahaan mengalami peningkatan dan variabel lainnya dianggap konstan, maka sebaliknya variabel penerapan business entity concept akan mengalami penurunan sebesar 0,164 .

\section{Pengujian secara Simultan (Uji F)}

Untuk mengetahui bahwa variabel bebas yang dirumuskan memiliki pengaruh simultan atau secara bersama-sama berpengaruh terhadap variabel terikat maka dilakukan uji $\mathrm{F}$ atau uji Fisher (Lind et al., 2014). Uji F ini juga dapat digunakan untuk mengetahui apakah model regresi yang telah dirumuskan mampu memprediksi variabel terikatnya. Ketentuan yang digunakan adalah jika nilai signifikansi F lebih kecil dari alpha $(0,05)$, maka model regresi yang dirumuskan sudah cocok dan mampu memprediksi penerapan business entity concept sebagai variabel terikatnya. Hasil pengujian secara simultan digambarkan dalam gambar 6 berikut ini. 


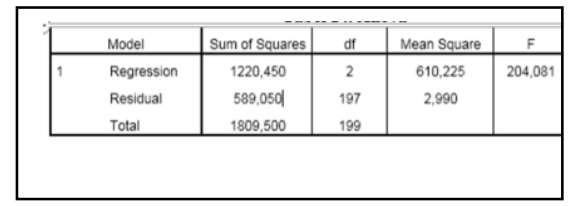

Gambar 6. Anova

Berdasarkan gambar 6 diatas dihasilkan nilai F hitung sebesar 204,081 dengan nilai signifikansi sebesar 0,000. Nilai signifikansi tersebut lebih kecil dari alpha $(0,05)$, sehingga menunjukkan bahwa H0 ditolak dan H1 diterima dengan kesimpulan bahwa secara simultan struktur organisasi dan ukuran perusahaan berpengaruh terhadap penerapan business entity concept.

2. Pengujian secara Parsial (Uji t)

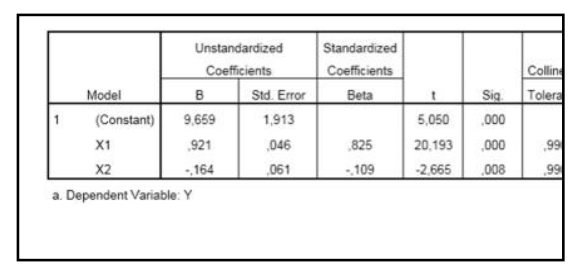

Gambar 7. Coefficients

Pada hasil pengujian diatas, terlihat bahwa nilai koefisien ( $\beta$ ) dari struktur organisasi (X1) bernilai positif dengan nilai signifikansi sebesar 0,000. Nilai ini lebih kecil jika dibandingkan dengan alpha $(0,05)$, sehingga menghasilkan keputusan bahwa Ho1 ditolak dan Ha1 diterima atau dengan kata lain struktur organisasi berpengaruh positif terhadap penerapan business entity concept.

Selanjutnya pada gambar 7 diatas, terlihat bahwa nilai koefisien $(\beta)$ dari ukuran perusahaan (X2) bernilai negatif dengan nilai signifikansi 0,008. Nilai signifikansi tersebut lebih besar dari alpha $(0,05)$ sehingga menghasilkan keputusan bahwa Ho2 diterima atau dengan kata lain ukuran perusahaan tidak berpengaruh positif terhadap penerapan business entity concept. Maka, kesimpulannya adalah variabel ukuran perusahaan berpengaruh negatif terhadap penerapan business entity concept.

\section{Koefisien Determinasi (R Square)}

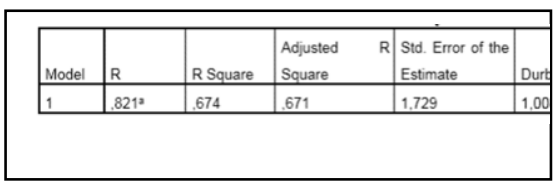

Gambar 8. Model Summary 
Hasil pengujian diatas menunjukkan bahwa nilai koefisien determinasi ( $R$ Square) adalah sebesar 0,674 atau 67,4\%. Hal ini menunjukkan bahwa variasi penerapan business entity concept (Y) yang dapat dijelaskan oleh Struktur organisasi (X1) dan ukuran perusahaan (X2) adalah sebesar 67,4\% sedangkan sisanya sebesar 32,6\% dijelaskan oleh variabel lainnya. Menurut Lind et al. (2014), nilai $R$ square yang berada pada angka diatas 50\% mengindikasikan bahwa kemampuan menjelaskan dari variabel bebas terhadap variabel terikatnya bersifat kuat, sehingga dapat disimpulkan bahwa variabel bebas yang dirumuskan yaitu struktur organisasi dan ukuran perusahaan telah mampu menjelaskan penerapan business entity concept sebagai variabel terikatnya.

\section{Pembahasan}

Seperti yang telah dipaparkan sebelumnya, bahwa tujuan penelitian ini adalah untuk mengetahui adanya pengaruh antara struktur organisasi dan ukuran perusahaan terhadap penerapan business entity concept. Hipotesis yang diuji secara parsial dalam penelitian terdiri dari dua hipotesis yang mana hasil pengujiannya akan dijelaskan berikut ini.

\section{Pengaruh Struktur Organisasi terhadap Penerapan Business Entity Concept}

Hasil pengujian untuk hipotesis pertama terkait struktur organisasi ditunjukkan pada hasil uji t yang memberikan nilai koefisien sebesar 0,921 dan nilai signifikansi sebesar 0,000. Karena nilai koefisien tersebut bernilai positif dan nilai signifikansi lebih kecil dari alpha $(0,05)$, maka dikatakan bahwa struktur organisasi berpengaruh positif terhadap penerapan business entity concept. Hasil penelitian ini sesuai dengan dugaan dari peneliti sebelumnya yaitu Gammahendra et al. (2014) dan Mt et al. (2014) yang menyatakan bahwa struktur organisasi memiliki kontribusi terhadap diterapkannya pengelolaan keuangan yang sesuai dengan prinsip akuntansi khususnya business entity concept.

Bagi suatu perusahaan, struktur organisasi merupakan suatu pembagian tugas dan juga wewenang dari masing-masing individu yang ada didalamnya termasuk pemilik perusahaan. Tidak dipungkiri bahwa dalam suatu perusahaan setiap individu memiliki kepentingan masing-masing, namun dengan adanya batasan wewenang dalam bentuk struktur organisasi tersebut, maka pemilik perusahaan tidak dapat melakukan tindakan atas kepentingan pribadinya meskipun pemilik perusahaan merupakan penguasa atau pemangku kepentingan utama. Tindakan yang dimaksud khususnya adalah dalam hal keuangan perusahaan. Dengan adanya struktur organisasi maka pemilik perusahaan ketika melakukan pengambilan dana dalam perusahaan harus melewati sejumlah prosedur yang sudah ditetapkan. Prosedur inilah yang merupakan salah satu sarana bagi perusahaan untuk menerapkan akuntansi yang baik terutama dalam konsep entitas 
(business entity concept) yang sudah lama menjadi penyebab kegagalan usaha pada suatu perusahaan khusunya usaha mikro, kecil dan menengah (UMKM).

\section{Pengaruh Ukuran Perusahaan terhadap Penerapan Business Entity Concept}

Hasil uji t untuk variabel ukuran perusahaan menghasilkan nilai koefisien sebesar -0,164 dan nilai signifikansi sebesar 0,008. Karena nilai koefisien tersebut bernilai negatif dan nilai signifikansi lebih kecil dari alpha $(0,05)$, maka dikatakan bahwa ukuran perusahaan memang berpengaruh terhadap penerapan business entity concept namun dengan pengaruh yang berkebalikan atau berpengaruh negatif. Hasil penelitian ini menjawab penelitian sebelumnya yaitu penelitian Prasetyorini (2013) dan Prasetya \& Gayatri (2016) yang menimbulkan pertanyaan apakah semakin besar suatu perusahaan membuat pengelolaan keuangan semakin baik.

Semakin besar ukuran suatu perusahaan maka total harta yang ada didalamnya juga semakin besar. Semakin besar total harta perusahaan maka pengelolaannya pun semakin kompleks. Namun, perlu diketahui bahwa pengelolaan yang semakin kompleks belum tentu mengindikasikan pengelolaan yang efektif dan efisien. Pengelolaan harta yang efektif dan efisien ditentukan oleh bagaimana penerapan akuntansi yang ada dalam perusahaan tersebut terutama pada konsep entitas. Perusahaan yang memiliki harta atau dana lebih sedikit, akan lebih mudah menerapkan business entity concept dibandingkan dengan perusahaan dengan harta yang lebih besar. Hal ini bisa terjadi karena dalam perusahaan yang besar, pemilik perusahaan merasa bahwa perusahaan tersebut berhasil karena usaha pribadinya dan akibatnya dia memiliki keinginan untuk menguasai perusahaan tersebut terutama dari sisi keuangannya.

\section{PENUTUP}

\section{Simpulan}

Dari berbagai analisis dan pembahasan yang sudah dipaparkan sebelumnya, maka dapat ditarik kesimpulan seperti berikut ini:

a. Struktur organisasi dan ukuran perusahaan secara bersama-sama bepengaruh terhadap penerapan business entity concept. Hal ini ditunjukkan pada hasil uji F yang memberikan nilai signifikansi sebesar 0,000

b. Struktur organisasi secara parsial berpengaruh positif terhadap penerapan business entity concept. Hal ini ditunjukkan pada hasil uji t yang memberikan nilai koefisien ( $\beta$ ) sebesar 0,921 dengan signifikansi 0,000 
c. Ukuran perusahaan secara parsial berpengaruh negatif terhadap penerapan business entity concept. Hal ini ditunjukkan pada hasil uji t yang memberikan nilai koefisien $(\beta)$ sebesar - 0,164 dengan signifikansi 0,008

d. Dilihat dari hasil koefisien determinasi ( $R$ Square), pengaruh struktur organisasi dan ukuran perusahaan terhadap penerapan business entity concept adalah sebesar $67,4 \%$, sedangkan sisanya sebesar $32,6 \%$ dijelaskan atau dipengaruhi oleh variabel lain.

\section{Saran}

Saran yang dapat diberikan oleh peneliti setelah melakukan penelitian ini adalah:

a. Masalah utama bagi suatu perusahaan teruatam UMKM adalah mengenai pengelolaan dana perusahaan. Pengelolaan dana yang efektif dan efisien dapat tercapai dengan menerapkan akuntansi yang baik. Salah satu langkah utama dalam menerapkan akuntansi yang baik adalah dengan menerapkan business entity concept, sehingga bagi UMKM yang masih sering mengalami kegagalan usaha akibat pengelolaan dana perusahaan dapat membentuk suatu struktur organisasi atau pembatasan wewenang dalam perusahaan.

b. Dalam menerapkan akuntansi yang baik, perusahaan tidak perlu memperdulikan ukuran kecilnya suatu perusahaan. Bagi perusahaan berskala kecil tidak perlu risau untuk menerapkan business entity concept sebagai langkah utama penerapan akuntansi yang baik. Hal ini dikarenakan hasil penelitian menunjukkan bahwa ukuran perusahaan berpengaruh negatif terhadap penerapan business entity concept.

c. Variabel bebas yang digunakan dalam penelitian ini masih sangat terbatas, ini terlihat pada hasil akhir yang menunjukkan bahwa masih terdapat 32,6\% dari variabel bebas lainnya terhadap penerapan business entity concept. Keterbatasan ini memunculkan saran kepada peneliti selanjutnya untuk melakukan perluasan penelitian. Perluasan penelitian yang dimaksud adalah dengan menambahkan variabel dan mungkin juga objek penelitian. 


\section{DAFTAR PUSTAKA}

Badan Pusat Statistik. (2015). Jumlah Perusahaan Industri di Indonesia Berdasar kan Skala Usaha, (Online), (http://www.bps.go.id/, diakses pada 2 November 2016)

Gammahendra, F., Hamid, D., \& Riza, M. F. (2014). Pengaruh Struktu r Organisasi terhadap Efektivitas Organisasi. Jurnal Administrasi Bisnis (JAB), 7(2), 1-10.

Ghozali, I. (2011). Aplikasi Analisis Multivariate dengan Program SPSS. Semarang: Badan Penerbit UNDIP.

Jane, O. (2012). Proses Internasionalisasi Perusahaan: Desain Strategi \& Organisasi Studi kasus UKM di Kota Bandung ). Lembaga Penelitian Dan Pengabdian Kepada Masyarakat Universitas Katolik Prahayangan, 1-55.

Jones, R. C. (2014). Considering an Entity's Business Model in Financial Reporting. Austin Journal of Accounting, Audit and Finance Management, 1(1), 1-5.

Lind, A. Douglas, William G. Marchal \& Samuel A. Wathen. (2014). Teknik-Teknik Statistika dalam Bisnis dan Ekonomi, Edisi 15, Buku 1. Jakarta: Salemba Empat.

Lind, A. Douglas, William G. Marchal \& Samuel A. Wathen. (2014). Teknik-Teknik Statistika dalam Bisnis dan Ekonomi, Edisi 15, Buku 2. Jakarta: Salemba Empat.

Mt, C. M., Amri, \& Majid, M. S. A. (2014). Pengaruh Gaya Kepemimpinan, Motivasi, Struktur Organisasi, dan Kompensasi terhadap Kinerja Karyawan serta Dampaknya pada Kinerja Program pascasarjana Universitas Syiah Kual. Jurnal Manajemen Pasca Sarjana Universitas Syiah Kuala, 3(1), 27-36.

Oesman, A. W. (2010). Konsep Entitas dalam Pencatatan Akuntansi Kredit Program Pada Koperasi Dan Lembaga Keuangan Mikro. Eksis, 6(1), 1314-1319.

Prasetya, P. J., \& Gayatri. (2016). Pengaruh Ukuran Perusahaan terhadap Manajemen Laba dengan Pengungkapan Corporate Social Responsibility sebagai Variabel Intervening. E-Jurnal Akuntansi Universitas Udayana, 14, 511-538.

Prasetyorini, B. F. (2013). Pengaruh Ukuran Perusahaan, Leverage, Price earning Ratio dan Profitabilitas Terhadap Nilai Perusahaan. Jurnal Ilmu Manajemen, 1, 1-196.

Pratama, I. G. B. A., \& Wiksuana, I. G. B. (2016). Pengaruh Ukuran Perusahaan dan Leverage terhadap Nilai Perusahaan dengan Profitabilitas sebagai Variabel Mediasi. E-Jurnal Manajemen Unud, 5(2), 1338-1367.

Purnamasari, D. (2013). Telisik Perlakuan Teori Entitas Usaha Mikro, Kecil dan Menengah. Jurnal Akuntansi Multiparadigma, 4(2), 188-197. Retrieved from www.jamal.ub.ac.id

Puspito. (2011). Perngaruh Struktur Kepemilikan pada Kinerja Perusahaan dengan Struktur Modal sebagai Pemoderasi. Riset Manajemen \& Akuntansi, 2(3), 84-113.

Putu, N., Pratiwi, Y., Yudiaatmaja, F., \& Suwendra, I. W. (2016). Pengaruh Struktur Modal dan Ukuran Perusahaan terhadap Nilai Perusahaan. E-Journal Bisma Universitas Pendidikan Ganesha, 4(1), 1-9. 
Said, K., Lubis, R., \& Putra, T. R. I. (2015). Pengaruh Struktur Organisasi, Desain Pekerjaan dan Budaya Organisasi terhadap Produktivitas Kerja Pegawai serta Implikasinya terhadap Kinerja Rumah Tahanan Negara Kelas IIB di Provinsi Aceh. Jurnal Manajemen Pasca Sarjana Universitas Syiah Kuala, 4(2), 140-148.

Sugiyono. (2009). Metode Penelitian Bisnis. Bandung: CV. Alfabeta.

Susilowati, F. (2016). Pola Struktur Organisasi Manajemen Kualitas pada Kontraktor Besar di Indonesia. Orbith, 12(1), 24-28.

Republik Indonesia. (1995). Undang-Undang No.9 Tahun 1995 tentang Usaha Kecil, LN No. 74 Tahun 1995 TLN No. 3611.

Yuhaida, H. N., Irmadariyani, R., \& Kurrohman, T. (2012). Penerapan Laporan Keuangan Organisasi Nirlaba Berdasarkan PSAK Nomor 45 ( Studi Kasus pada Lembaga Pendidikan Ma' arif NU Assalbiyah ), 45, 1-7.

Zuhri, S. (2014). Analisis Pengembangan Usaha Kecil Home Industri Sangkar Ayam dalam Rangka Pengentasan Kemiskinan. Jurnal Manajemen Dan Akuntansi, 2(3), 1-16. 